\title{
Assessing and advancing marketing's value propositions: a disciplinary dialog
}

\author{
Stephen L. Vargo ${ }^{1}$ \\ Published online: 24 November 2020 \\ (C) Academy of Marketing Science 2020
}

An essential function of any organized body is the regular reassessment of its value propositions - the way in which its various internal and external constituencies perceive the benefits it affords (Vargo 2020). Academic disciplines are no exception. This is no easy task for any discipline, but it is perhaps especially difficult for "applied" disciplines, such as marketing, since both the specification of its primary stakeholders and its mission are contentious issues. At one level, it can be argued that the primary "customer" is the firm and the mission of the marketing discipline is to provide prescriptive insights for the firm's execution of marketing activities. From a more transcending level, however, it can also be argued that, because markets - broadly conceptualized - are the essential venues for resource application and exchange for societal well-being (Vargo and Lusch 2017), stakeholders are infinite and the mission of the marketing discipline is the facilitation of societal sustainability.

The good news is that marketing, as an academic discipline, has a rich history of reassessment of its purpose, scope and theoretical foundations through strategic introspection. Examples can be found in the debates over the broadening of its focus (e.g., Kotler and Levy 1969; Lazniak and Michie 1979), the discussion around a macro-to-micro- (actually meso-) level, managerial focus initiated by Alderson (1957, see El-Ansary et al. 2017), periodic discussions about the scientific foundations of marketing (e.g., Anderson 1983; Arndt 1985), the extended definition-of-marketing debate centered on the 2004 American Marketing Association revised definition (Lusch 2007), and the ongoing recognition of and discussion about the academicpractice "gap" (e.g., Lilien et al. 2002), to name a few. The bad news is that all of this introspection has seldom clarified either the mission or value propositions of marketing and more accurately, has probably contributed to what many characterize as "fragmentation" (e.g., Coulter 2016).

Stephen L. Vargo

svargo@hawaii.edu

1 University of Hawai'i at Manoa, HI 96822 Honolulu, USA
As a journal positioned to be the premier conceptual-only journal for marketing, it is appropriate that AMS Review facilitate continuing dialog and debate about these and related issues of marketing's identity and purpose. It was with this in mind that I decided to publish a somewhat controversial article by Martin Key, Terry Clark, OC Ferrell, David Steward and Leyland Pitt (this issue) titled "Marketing's theoretical and conceptual value proposition: opportunities to address marketing's influence." The article had originally been submitted in response to a call for papers on "Advancing Conceptual, Theoretical Articles in Marketing: Importance, Writing, and Reviewing," a special section subsequently published in the June 2020 issue of AMS Review. It addressed how conceptual, theoretical articles could help remedy a host of related problems the authors see with academic marketing, especially myopic views of rigor and relevance.

The Key et al. submission had mixed reviews, partly because of its unusual format - five linked essays from five scholarsbut also because of its rather critical stand on the state of contemporary, academic marketing, which elicited both favorable and unfavorable evaluations. It became apparent rather quickly that I was unlikely to receive reviewer consensus on the manuscript but decided to move it forward anyway, in part because of the importance of the issues it raised and also because, in my opinion, they were being raised by some very credible marketing scholars. Thus, I removed it from consideration for the special issue, published it online, and invited other interested scholars to weigh in. That process has resulted in six commentaries representing a variety of viewpoints, all published in this issue, along with the original Key, et al. article. The commentaries are quite diverse, both in their level of agreement with Key et al. and in their specific suggestions.

Russel Belk (this issue), in perhaps the most provocative commentary, extends the Key et al. claims, proclaiming marketing to be "dead or dying" because brand control has shifted from marketers to customers and many other traditional marketing functions have shifted to big data and data analytics. He suggests several "end-runs" around traditional marketing 
concerns and approaches and reapproaching marketing through abductive reasoning and boundary-spanning perspectives.

Ruth Bolton (this issue) takes a more measured approach, arguing that marketing academics have a mission of conducting research that has benefit to individuals, organizations, society, and the environment. She points toward the need for more high-impact articles in marketing and identifies a series of steps for moving conceptual research closer to that goal.

Julia Ferher (this issue), an emerging scholar with appointments both in Europe and New Zealand, provides a positive and insightful perspective. Essentially, she argues that, while the concerns raised by Key et al. are legitimate, some of the solutions, or at least their seeds, can be found in the activity at the edges of the very discipline they are critiquing.

Tomas Hult and Forrest V. Morgeson (this issue) take a quite novel approach to commenting on the Key et al. article by constructing a satisfaction-focused, exit-voice-loyalty theory. Through this theoretical lens, they evaluate marketing's value propositions optimistically.

Shelby Hunt (this issue) takes a historical look at the development of marketing, based on a combination of Willkie and Moore's $(2003,2006)$ model of four Eras of marketing development plus his own (Hunt 2018) "five stage" modification. He sees Era IV (1980-2020) as being characterized by fragmentation and the Key et al. article as potentially presaging a needed legitimization process involving the "de-institutionalization" and "re-institutionalization" of the marketing discipline as part of Era V (2000-??).

Rajan Varadarajan (this issue) takes the most dissenting stance in relation to the Key et al. theses. He especially focuses on the critical role of rigor in research and its relationship to relevance and also argues that marketing's lack of scholarly impact on other business disciplines is probably more a reflection of those other disciplines' willingness to import than the exportability of academic marketing's research.

If there is a common thesis in these commentaries, it is probably that academic marketing needs to move beyond traditional approaches, what Belk calls the "muddy middle" and Hunt calls "fragmentation," to find newer, more integrative perspectives, what Bolton identifies as a change in the "dominant logic." In short, academic marketing needs additional work on (re)conceptualizing its mission and value propositions. Facilitating this process is, of course, consistent with the purpose of AMS Review. Thus, I encourage interested scholars in continuing to use the journal as a venue for related discussion and dialog.

To this end, and in recognition of the 50th Anniversary of the Academy of Marketing Science, we have issued a call for papers for a special issue of AMS Review titled "The Past and
Future of Marketing Theory and Practice: A tribute to the 50th anniversary of the Academy of Marketing Science." The driving idea is to reflect on the developmental and evolutionary paths of academic marketing and to consider the conceptual, theoretical, and practical work that needs to be accomplished as we make our way forward. I believe the Key et al. article, together with the commentaries in this issue, provide a meaningful contribution toward that endeavor. The editorial team comprises OC Ferrell of Auburn University and past president of AMS, Bo Edvardsson with Karlstad University in Sweden, Jodie Conduit with the University of Adelaide, Australia and me. It is being orchestrated with the publication committee of AMS. We invite all interested scholars to respond to this CFP.

\section{References}

Alderson, R. (1957). Marketing behavior and executive action. Homewood: Irwin.

Anderson, P. F. (1983). Marketing, scientific progress, and scientific method. Journal of Marketing, 47(Fall), 18-31.

Arndt, J. (1985). On making marketing science more scientific: role of orientations, paradigms, metaphors, and puzzle solving. Journal of Marketing, 49(Summer), 11-23.

Coulter, R. A. (2016). From fragmentation to imagination; moving to Marketing's next Era. Journal of the Academy of Marketing Science, 6(3-4), 132-141.

El-Ansary, A., Shaw, E., \& Lazer, W. (2017). Marketing's identity crisis: insights from the history of marketing thought. Journal of the Academy of Marketing Science, 8(1-2), 5-17.

Hunt, S. D. (2018). Advancing marketing strategy in the marketing discipline and beyond: From promise, to neglect, to prominence, to fragment (to promise?). Journal of Marketing Management, 34(12), 16-51.

Kotler, P., \& Levy, S. J. (1969). Broadening the concept of marketing. Journal of Marketing, 88(Jan), 10-15.

Lazniak, G. R., \& Michie, D. A. (1979). The social disorder of broadening the concept of marketing. Journal of the Academy of Marketing Science, 7(2), 214-232.

Lilien, G., Ragaswamy, A., van Bruggen, G. H., \& Wierenga, B. (2002). Bridging the marketing theory-practice gap with marketing engineering. Journal of Business Research, 55(2), 111-121.

Lusch, R. F. (2007). Marketing's evolving identity: Defining our future. Journal of Public Policy in Marketing, 26(2), 261-268.

Vargo, S. L., \& Lusch, R. F. (2017). Service-Dominant Logic in 2025. International Journal of Research in Marketing, 34(1), 46-67.

Vargo, S. L. (2020). From Promise to Perspective: Reconsidering Value Propositions from an S-D Logic Orientation. Industrial Marketing Management, 87, 309-311.

Wilkie, W. L., \& Moore, E. S. (2003). Scholarly research in marketing: Exploring the "4 Eras" of thought development. Journal of Public Policy \& Marketing, 22(2), 116-146.

Wilkie, W. L., \& Moore, E. S. (2006). Macromarketing as a pillar of marketing thought. Journal of Macromarketing, 26(2), 224-232.

Publisher's note Springer Nature remains neutral with regard to jurisdictional claims in published maps and institutional affiliations. 